\title{
PENGEMBANGAN METODOLOGI PEMBELAJARAN PENDIDIKAN AGAMA ISLAM: KARAKTERISTIK, PRINSIP DAN DIMENSINYA
}

\begin{abstract}
1 Universitas Ibrahimy, Situbondo 2 Program Doktor UIN Kiai Haji Ahmad Shiddiq, Jember
\end{abstract}

\begin{abstract}
Teacher has existencial strategic in delivering student to reach learning success. Learning success is not reached easily without there is an excellent planning by the teacher. Learning method is not the only one of learning success determinant indeed, but the excellent teaching-learning process of Islamic religion education will not be successful without the right methodology. Because of that this article tried to give description about the urgency of Islamic religious education learning methodology development, principle and basis in developing Islamic religion education learning methodology, as well as the Islamic religion education characteristic.
\end{abstract}

Keywords: Learning Methodology Development, PAI

\section{PENDAHULUAN}

Pendidikan merupakan sesuatu yang sangat dibutuhkan oleh manusia. Melalui pendidikan dapat melahirkan kualitas manusia secara utuh baik secara fisik maupun psikis. Pendidikan akan menjadikan manusia memiliki pengetahuan, keterampilan, dan sifat-sifat terpuji sehingga mampu menghadapi semua problematika kehidupan yang dihadapi. Pendidikan juga merupakan usaha sadar dan terencana untuk mewujudkan suasana belajar dan proses pembelajaran agar peserta didik secara aktif mengembangkan potensi dirinya untuk memiliki

${ }^{1}$ Moh. Nawafil and Junaidi Junaidi, "Revitalisasi Paradigma Baru Dunia Pembelajaran Yang Membebaskan," Jurnal kekuatan spiritual keagamaan, pengendalian diri, kepribadian, kecerdasan, akhlak mulia, serta ketrampilan yang diperlukan dirinya, masyarakat, bangsa, dan negara. ${ }^{1}$

Pendidikan atau pembelajaran terjadi minimal di tiga jenis lembaga, yaitu lembaga pendidikan formal, pendidikan non-formal, dan pendidikan informal. Pendidikan formal adalah jalur pendidikan yang terstruktur dan berjenjang yang terdiri dari pendidikan dasar, pendidikan menengah, dan pendidikan tinggi. Adapun pendidikan non-formal adalah jalur pendidikan di luar pendidikan formal yang dapat dilaksanakan secara terstruktur dan berjenjang. ${ }^{2}$ Sedangkan

Pendidikan Islam Indonesia 4, no. 2 (April, 2020): 215-25, doi:10.35316/jpii.v4i2.193.

2 H.A.R. Tilaar, Pedagogik Teoritis Untuk Indonesia (Jakarta: Kompas, 2015), 67. 
pendidikan informal adalah jalur pendidikan dalam keluarga atau lingkungan. Dilihat dari aspek materi atau isi yang disampaikan, pendidikan menjelma ke dalam empat jenis, yaitu pendidikan kedinasan, pendidikan keagamaan, pendidikan jarak jauh, dan pendidikan khusus dan layanan khusus. Pendidikan agama dan pendidikan keagamaan merupakan salah satu jenis pendidikan yang memiliki peran sangat penting dalam konteks kehidupan berbangsa dan bernegara. Pendidikan agama dan pendidikan keagamaan memiliki tujuan mengembangkan kemampuan peserta didik dalam memahami, menghayati dan mengamalkan nilai-nilai agama yang menyerasikan penguasaannya dalam ilmu pengetahuan, teknologi, dan seni.

Munculnya era globalisasi seperti saat ini membuka wawasan dan kesadaran masyarakat dengan sejumlah harapan sekaligus kecemasan. Harapan-harapan ini muncul karena ada perbaikan kualitas hidup dan kehidupan di suatu sisi sebagai akibat penguasaan ilmu pengetahuan dan teknologi (IPTEK) serta informasi dan teknologi (INFOTEK). Namun sisi lain muncul juga kecemasan-kecemasan, yang disebabkan oleh adanya perubahan yang terlalu cepat sehingga kondisi masyarakat sulit untuk beradaptasi. Teknologi dan informasi dalam rentang waktu yang singkat telah menjadi salah satu landasan bagi masyarakat modern, pemahaman dan penguasaan tentang teknologi dan informasi merupakan jantung dalam dunia pendidikan. ${ }^{3}$ Teknologi informasi sudah merasuk ke dalam kehidupan sehari-hari khususnya di dunia pendidikan. Teknologi informasi yang mendobrak batas ruang dan waktu menciptakan peluang dan masalah bagi dunia pendidikan kita.

Pendidikan adalah proses dalam rangka mempengaruhi peserta didik supaya mampu menyesuaikan diri sebaik mungkin dengan lingkungan yang akan menimbulkan perubahan pada dirinya yang memungkinkan sehingga berfungsi sesuai kompetensinya dalam kehidupan masyarakat. ${ }^{4}$ Hasil-hasil kajian belajar membuahkan suatu akumulasi prinsip-prinsip belajar yang dapat berulang-ulang diverifikasi.

\footnotetext{
3 Rusman, Pembelajaran Berbasis Teknologi Informasi Dan Komunikasi (Jakarta: Raja Grafindo Persada, 2012), 54.
}

Prinsip-prinsip ini menyumbang pembentukan suatu kumpulan pengetahuan tentang belajar terus menerus berkembang keluasan dan ketelitiannya.

Perubuhan-perubahan yang dapat berpengaruh dalam dunia pendidikan tentu harus mendapat penanganan intensif tersendiri bagi praktisi pendidikan dan pendidik secara umum. Perkembangan teknologi dan arus globalisasi juga berdampak pada mata pelajaran pendidikan agama Islam yang mau tidak mau harus berinovasi agar peserta didik tetap menyukai dan mencintai belajar materi pendidikan agama Islam. Tidak terlepas dari urgensitas mata pelajaran pendidikan Islam sebagai landasan dalam menjaga karaktek dan akhlak siswa. Maka dari itu, pengembangan metode pembelajaran bagi pendidik PAI untuk peserta didik sangat diperlukan mengingat perubahan-perubahan teknologi dan arus globalisasi yang berkembang semakin pesat. Untuk itu pendidik agama Islam harus mengetahui lebih mendalam mengenai aspekaspek pengembangan metode pembelajaran PAI yang mana kesemua itu akan dijelaskan pada pembahasan berikutnya.

\section{PEMBAHASAN}

\section{Karakteristik Pendidikan Agama Islam}

Sebelum lebih jauh membahas tentang karakteristik pendidikan Islam maka haruslah kita mengetahui apakah yang dimaksud dengan pendidikan Islam itu sebenarnya. Secara esensial pendidikan Islam selalu saja dikaitkan dengan bagaimana agar peserta didik mampu menerapkan nilai-nilai moral dan akhlak agar senantiasa dapat mencerminkan sesosok cendikiawan yang berakhlakhul karimah. Adapun pengertian dari pendidikan Islam menurut hasil rumusan Seminar Pendidikan Islam se-Indonesia tahun 1960 memberikan pengertian bahwa pendidikan Islam adalah sebagai bimbingan terhadap pertumbuhan rohani dan jasmani menurut ajaran Islam dengan

\footnotetext{
4 Sri Suyanta, "Transformasi Intelektual Islam Ke Barat," Jurnal Ilmiah Islam Futura 10, no. 02 (February 2011): 18.
} 
hikmah mengarahkan, mengajarkan, melatih, mengasuh dan mengawasi berlakunya semua ajaran Islam. Istilah membimbing, mengarahkan dan mengasuh serta mengajarkan atau melatih mengandung pengertian usaha mempengaruhi jiwa anak didik melalui proses setingkat demi setingkat menuju tujuan yang ditetapkan yaitu menanamkan taqwa dan akhlak serta menegakkan kebenaran sehingga terbentuklah manusia yang berpribadi dan berbudi luhur sesuai ajaran Islam. ${ }^{5}$

Di sisi lain Muhammad Fadhil berpendapat bahwa pendidikan Islam adalah upaya mengembangkan, mendorong, serta mengajak manusia lebih maju dengan berlandaskan nilai-nilai yang tinggi dan kehidupan yang mulia, sehingga terbentuk pribadi yang lebih sempurna, baik yang berkaitan dengan akal, perasaan, maupun perbuatan. ${ }^{6}$ Definisi tersebut mempunyai tiga prinsip penting pendidikan Islam, yaitu yang pertama ialah pendidikan merupakan proses perbantuan pencapaian tingkat keimanan dan berilmu yang disertai dengan amal shaleh. Kedua, ialah sebagai model maka Rasulullah sebagai uswatun hasanah yang dijamin Allah dengan akhlak yang mulia. Ketiga, pada manusia terdapat potensi baik dan buruk, potensi negatif seperti lemah, tergesa-gesa, berkeluh kesah, dan ruh Allah ditiupkan kepadanya pada saat penyempurnaan penciptaannya. Oleh karena itu, pendidikan ditujukan sebagai pembangkit potensi baik yang ada pada anak didik dan mengurangi potensinya yang jelek.

5 Fathur Rohman, "Evaluasi Kurikulum Metodologi Pembelajaran PAI Pada Prodi PAI UNISNU Jepara," Tarbawi: Jurnal Pendidikan Islam 12, no. 2 (2015), https://ejournal.unisnu.ac.id/JPIT/article/view/510.

${ }^{6}$ Noni Agustina and Ratnawati Susanto, "Persepsi Guru Terhadap Pengembangan Profesionalisme Melalui Pelatihan Media Pembelajaran Berbasis Edmodo," in Prosiding Seminar
Sehingga dari paparan di atas dapat ditarik kesimpulan mengenai pengertian pendidikan Islam adalah suatu proses untuk mengembangkan segala potensi yang dimiliki oleh peserta didik untuk mencapai tujuan yang diharapkan sesuai dengan ajaran Islam sehingga terbentuk kepribadian yang luhur dan insan kamil.

Di dalam memahami pendidikan Islam tentunya pendidikan Islam memilki beberapa karakteristik dan berikut akan disajikan secara garis besar karakteristik pendidikan Islam. Pendidikan Islam sebagai satu mata rantai dari syariat Islam, memiliki ciri khusus yang sama dengan kekhususan Islam sendiri, yaitu syamilkamil-mukatamil (sistem yang integral-sempurnadan menyempurnakan). Integritas sistem pendidikan Islam ini secara garis besar mencangkup seluruh aspek kehidupan manusia, dapat dirinci dengan rincian sebagai berikut ${ }^{\top}$ :

1. Pendidikan akidah, yang dimaksud dengan pendidikan akidah adalah mengikat indifidu dengan dasar-dasar syariah Islamiyah. Metode pendidikan ini adalah menumbuhkan pemahaman terhadap dasar-dasar keimanan dan ajaran Islam yang bersandarkan pada wasiat-wasiat Rasulullah Saw dan petunjuknya.

2. Pendidikan moral dan akhlak, yang dimaksud pendidikan moral adalah pendidikan mengenai dasar-dasar moral dan keutamaan perangai, tabiat yang harus dimiliki dan dijadikan kebiasaan oleh individu sejak masa

Nasional Pendidikan Teknik Informatika, 2017, 44-48, http:/ / pti.undiksha.ac.id/senapati.

7 Fitri Erning Kurniawati, "Pengembangan Bahan Ajar Aqidah Ahklak Di Madrasah Ibtidaiyah," Jurnal Penelitian 9, no. 2 (2015): 367, doi:10.21043/jupe.v9i2.1326. 
analisa hingga ia menjadi seorang mukallaf, pemuda yang mengarungi lautan kehidupan. Tidak diragukan lagi bahwa keutamaankeutamaan moral, perangai dan tabiat merupakan salah satu buah iman yang mendalam, dan perkembangan religius yang benar.

3. Pendidikan jasmaniah, di mana pendidikan Islam sangat memperhatikan fisik tiap-tiap muslim. Apabila bicara tentang fisik dalam pendidikan, yang dimaksud bukan hanya otot-ototnya, panca indranya dan kelenjarkelenjarnya, tetapi juga potensi energik yang muncul dari fisik dan terungkap melalui perasaan. Sehingga nantinya dapat menghantarkan umat Islam yang sehat dan memaksimalkan potensi ibadah secara totalitas kepada Allah SWT. Islam mendidik ummatnya dengan memberikan rangsangan yang baik sebagaimana dalam sabda Rasulullah Saw "mukmin yang kuat lebih baik dan lebih dicintai dari pada mukmin yang lemah." Islam juga mengajarkan aturan-aturan yang sehat dalam makan, minum, dan tidur. Mendidik juga untuk kesehatanya, dengan selalu menganjurkan olah raga dan menjauhkan diri dari penyebab-penyebab kelemahan.

4. Pendidikan intelektual, maksud pendidikan intelektual adalah pembentukan dan pembinaan berfikir indifidu dengan segala sesuatu yang bermanfaat, ilmu pengetahuan, hukum, peradaban ilmiah dan modernism. Serta kesadaran berfikir dan berbudaya. Dengan demikian ilmu, rasio dan peradaban individu tersebut benar-benar dapat dibina. Akal adalah kekuatan manusia yang paling besar dan merupakan pemberian Allah yang paling berharga. Sekaligus Alquran memberikan perhatian yang sangat besar terhadap perkembangan akal ini. Alquran mendidik akal dengan begitu banyak ayat-ayat alam semesta untuk jadi bahan perenungan. Tapi bukan perenungan itu yang menjadi tujuannya, melainkan mendidik akal agar cermat, cerdas, dan akurat dalam berfikir dan bersikap serta menempuh jalan idup. Beberapa ayat terkait, seperti di QS.Al-Mulk (67) : 4, "Kemudian pandanglah sekali lagi niscaya penlihatanmu akan kembali kepadamu dengan tidak menemukan sesuatu cacat dan penglihatanmu itupun dalam keadaan payah.” Juga pada QS. Faathir (35) : 40, “katakanlah: terangkanlah kepada-ku tentang sekutu-sekutumu yang kamu seru selain allah. Perlihatkanlah kepadaku (bahagian) manakah bumi ini yang telah mereka ciptakan atau mereka mempunyai dalam (penciptaan) langit atau adakah kami member kepada mereka sebuah kitab sehingga mereka mendapat keterangan-keterangan yang jelas dari padanya? Sebenarnya orang-orang yang zalim itu sebahagian dari mereka tidak menjanjikan kepada sebahagian yang lain, melainkan tipuan belaka."

5. Pendidikan psikis, yang dimaksud penddikan psikis adalah mendidik individu supaya bersikap berani, berterus terang, merasa sempurna, suka berbuat baik terhadap orang lain, menahan diri ketika marah dan senang kepada seluruh bentuk keutamaan psikis dan moral secara keseluruhan. Tujuan pendidikan ini adalah membentuk, menyempurnakan dan menyeimbangkan keperibadian individu, sehingga mampu melaksanakan kewajibankewajibannya dengan baik dan sempurna.

6. Pendidikan sosial, yang dimaksud pendidikan sosial adalah mendidik individu agar terbiasa 
menjalankan adab-adab sosial yang baik dan dasar-dasar psikis yang mulia dan bersumber pada akidah Islamiyah yang abadi serta perasaan keimanan yang mendalam, agar di dalam masyarakat nanti mereka bisa tampil dengan pergaulan dan adab yang baik, keseimbangan akal sehat yang matang dan tindakan yang bijaksana.

7. Pendidikan seksual, yang dimaksud pendidikan seksual adalah upaya pengajaran, penyadaran dan penerangan tentang masalahmasalah seksual yang diberikan kepada individu, sejak ia mengerti masalah-masalah yang berkenaan dengan seks, naluri dan perkawinan. Sehingga, jika anak tumbuh menjadi seorang pemuda, dia dapat memahami masalah yang dihalalkan dan yang diharamkan. Bahkan mampu menerapkan tingkah laku islami sebagai akhlak, kebiasaan, dan tidak akan mengikuti syahwat dan caracara hedonism. Di antara bagian pendidikan ini adalah mendidik adab-adab meminta ijin, adab memandang, keharusan mengajarkan tentang hukum-hukum pada masa pubertas dan masa baligh, perkawinan dan hubungan seksualitas, istighfar (mensucikan diri) bagi orang yang belum mampu menikah, dan lain sebagainya. Selain syamil, pendidikan Islam juga memiliki keistimewaan lain yaitu, berdimensi manusiawi dengan paket pembinaan yang bertahap dan tawazun (penuh keseimbangan dalam segala sisi kehidupannya). Selan juga terus megikuti perkembangan zaman serta tetap menjaga orisinalitas.
Itulah garis besar karakteristik pendidikan agama Islam yang keberlangsungannya sangat bergantung pada manusia dalam pelaksanaannya, perangkat serta kekontinyuitas seluruh masyarakat dalam merealisir konsep pendidikan itu pada tujuan yang benar. Yakni upaya sungguh-sungguh (jihad) menciptakan masyarakat yang seluruh aktifitas ritual, sosial, intelektual, dan fisikalnya tunduk kepada tata aturan maha pencipta alam semesta. ${ }^{8}$

\section{Urgensitas Pengembangan Metodologi}

\section{Pembelajaran PAI}

Manusia dalam kenyataan hidupnya menunjukkan bahwa ia membutuhkan suatu proses belajar yang memungkinkan dirinya untuk menyatakan eksistensinya secara utuh dan seimbang. Manusia tidak dirancang oleh Allah Swt untuk dapat hidup secara langsung tanpa proses belajar terlebih dahulu untuk memahami jati dirinya dan menjadi dirinya. Dalam proses belajar itu seseorang saling tergantung dengan orang lain. Proses belajar itu dimulai dengan orang terdekatnya. Proses belajar itulah yang kemudian menjadi basis pendidikan. Aktivitas pendidikan terkait dengan perubahan yang secara moral bersifat lebih baik, ciri perubahan atau kemajuan secara fundamental adalah terjadinya perkembangan internal diri manusia yaitu keimanan dan ketakwaan, bukan hanya perubahan eksternal yang cenderung bersifat material yang dapat menghancurkan keimanan dan ketakwaan manusia.

Dalam kehidupan modern seperti sekarang ini, produk pendidikan sering hanya

${ }^{8}$ Fadli Muh Suyuti R, Dasar-Dasar Pendidikan Islam (Jakarta: Malupu, 2008), 19. 
diukur dari perubahan eksternal yaitu kemajuan fisik dan material yang dapat meningkatkan pemuasan kebutuhan manusia. Masalahnya adalah bahwa manusia dalam memenuhi kebutuhan sering bersifat tidak terbatas, bersifat subyektif yang sering justru dapat menghancurkan harkat kemanusiaan yang paling dalam adalah kehidupan rohaninya. ${ }^{9}$ Produk pendidikan berubah menghasilkan manusia yang cerdas dan terampil untuk melakukan pekerjaannya, tetapi tidak memiliki kepedulian dan perasaan terhadap sesame manusia. Ilmu pengetahuan yang dikembangkan menjadi instrument kekuasaan dan kesombongan untuk memperdayai orang lain, kecerdikannya digunakan untuk menipu dan menindas orang lain, produk pendidikan berubah menghasilkan manusia yang serakah dan egois.

Ketidakberhasilan tertanamnya nilai-nilai rohaniyah (keimanan dan ketakwaan) terhadap peserta didik dewasa ini sangat terkait dengan dua faktor penting dalam proses pembelajaran di samping banyak faktor yang lain, kedua faktor tersebut adalah strategi pembelajaran serta orang yang menyampaikan pesan-pesan ilahiyah (guru). Dalam sistem pendidikan Islam seharusnya menggunakan metode pendekatan yang menyeluruh terhadap manusia, meliputi dimensi jasmani dan rohani (lahiriyah dan batiniyah), di samping itu keberhasilan sebuah proses pembelajaran sangat ditunjang oleh kepribadian setiap penyampai pesan (guru). ${ }^{10}$

\footnotetext{
${ }^{9}$ Abd Muqit, Moh Nawafil, and Mohammad Tohir, "Vitality of Educators ' Work in Counteracting Students' Immoral Behavior: The Study of Nafs, Qalb and Aql Approaches and Their Theoretical Implementation" 5, no. 10 (2021): 2431.

${ }^{10}$ Abdul Muid, "Stategi Penerapan Metodologi Pembelajaran PAI Dalam Meningkatkan Budaya Religiusitas Siswa-Santri
}

Dari banyak faktor yang menyebabkan gagalnya pendidikan, metode pembelajaran dan mentalitas pendidik memerlukan perhatian khusus. Sebagus apapun tujuan pendidikan, jika tidak didukung oleh dua faktor tersebut, yaitu metode yang tepat dan mentalitas pendidik yang baik, sangat sulit untuk dapat tercapai dengan baik. Sebuah metode akan mempengaruhi sampai tidaknya suatu informasi secara memuaskan atau tidak, bahkan sering disebutkan cara atau metode kadang lebih penting daripada materi itu sendiri. Oleh karena itu pemeliharaan metode pendidikan Islam harus dilakukan secara cermat disesuaikan dengan berbagai faktor terkait sehingga hasil pendidikan memuaskan. ${ }^{11}$

Masyarakat madani yang menjadi cita-cita tidak hanya pada bahan hafalan dan pengetahuan peserta didik, tetapi ada perubahan sikap dan perilaku yang sesuai dengan konsep yang dimaksud, yaitu masyarakat yang religious, demokratis, tertib dan sadar hukum, taat hukum, menghargai hak asasi manusia, kreatif mandiri dan percaya diri. Memiliki semangat kompetitif dengan semangat persaudaraan, universal (pluralistic). Inilah problem mendasar dunia pendidikan saat ini sehingga mengharuskan melakukan perubahan mendasar pada metodologi pendidikan, yaitu proses perubahan dari idealistis ke praktis, dari kognitif ke afektif dan psikomotorik. Harapnnya pendidikan mampu mempersiapkan peserta didik menghadapi dan menghargai kehidupan nyata, bukan hanya dunia gagasan yang hafal dan dimengerti. Artinya

Di TPQ Roudlotul Janah Gantang Baru-Boboh-MengantiGresik Jawa Timur," RISDA: Jurnal Pemikiran Dan Pendidikan Islam 4, no. 2 (2019): 12.

11 Qomari Anwar, Pendidikan Sebagai Karakter Budaya Bangsa (Jakarta: UHAMKA Press, 2003), 42. 
wawasan keislaman mampu ditransformasikan secara sistematik dalam kehidupan nyata masyarakat dan bukan dalam kehidupan konsep, karena kondisi sekarang ini pergeseran paradigma semakin cepat dan kecepatan perubahan sulit diprediksi.

Pergeseran paradigma saat ini juga akan berpengaruh terhadap metodologi pendidikan dan peserta didik akan belajar melalui internet, web, home page, cd room, yang merupakan alat bantu yang akan mempercepat proses distributed knowledge. Fungsi pendidik sebagai mediator dalam ilmu pengetahuan dan pengajar (guru dan dosen) bukan satu satunya sumber pengetahuan, tetapi merupakan salah satu sumber dari sekian sumber pengetahuan yang ada. Peserta didik akan lebih banyak belajar dari media elektronik dari pada guru atau buku.

Tugas utama pendidik (guru atau dosen) lebih terfokus mengajar peserta didik untuk mengakses sendiri informasi dan pengetahuan yang diperlukan untuk menambah pengetahuan. Proses pembelajaran lebih cenderung menggunakan learning based daripada teaching based yang akan menjadi kunci pengembangan peserta didik. Metodologi lebih diorientasikan kepada cara mengaktifkan peserta didik, cara untuk menemukan, cara untuk memecahkan masalah menjadi fenomena saat ini, sehingga metodologi pembelajaran semacam itu akan menjadi kunci pengembangan peserta didik yang berkualitas.

Untuk itu perlu ada kesadaran bahwa perubahan metodologi belajar mengajar pada akhirnya harus membawa peserta didik untuk belajar lebih lanjut dan berkemampuan memilih, serta lebih mengutamakan proses belajar dalam perspektif "menjadi" di atas perspektif "memiliki".

Kemudian dalam sisi metode dan prinsip pembelajaran diarahkan pada outcomes competency. Peningkatan relevansi dengan kebutuhan masyarakat dan dunia kerja serta kompetensi yang dimiliki peserta didik harus dapat diaplikasikan dan diamati dengan acuan standar. Penggunaan penilaian dan evaluasi secara komprehensif, pengakuan terhadap kompetensi relative yang bebas dari cara atau strategi penguasaannya dan fleksibilitas dalam mengakses perubahan, mengakses kesempatan dan pengembangan sikap serta perilaku berkarya sesuai dengan profesinya sebagai outcomes competency diharapkan dapat mengembangkan dan membangun tiga pilar ketrampilan, yaitu: (1) learning skills, yaitu ketrampilan mengembangkan dan mengelola pengetahuan dan pengalaman serta kemampuan dalam menjalani belajar sepanjang hayat. (2) Thingking skills, yaitu ketrampilan berfikir kritis, kreatif dan inovatif untuk menghasilkan keputusan dan pemecahan masalah secara optimal. (3) Life skills, yaitu ketrampilan hidup yang mencakup kematangan emosi dan social yang bermuara pada daya juang, tanggung jawab dan kepekaan social yang tinggi. Dari semua di atas dapat dikatakan bahwa sebenarnya kompetensi standar yang diinginkan dalam proses pendidikan Islam adalah penguasaan nilai-nilai islamiyah, penguasaan pengetahuan (knowledge), penguasaan ketrampilan dan kemahiran berkarya (skill), memiliki attitude dan ability tertentu. ${ }^{12}$

\footnotetext{
${ }^{12}$ Hujair AH Sanaky, Media Pembelajaran (Yogyakarta: Safiria Insania Press, 2009), 191.
} 
Akhirnya dapat dikatakan bahwa metodologi pendidikan bukan merupakan satusatunya faktor penentu keberhasilan belajar, tetapi proses belajar mengajar pendidikan Islam tidak akan berhasil tanpa metodologi yang tepat dan benar. Metodologi pendidikan yang digunakan dalam proses pendidikan agama Islam adalah pembelajaran dengan menggunakan paradigma holistik, rasional, partisipatori, pendekatan empiric deduktif, sehingga menghasilkan peserta didik yang berkualitas, kreatif, inovatif yang mampu menerjemahkan dan menghadirkan agama dalam perilaku sosial dan individual di tengah-tengah kehidupan masyarakat modern.

Selain itu, mampu mengembangkan dan mengamalkan ilmu serta keahliannya dengan bersumber pada ajaran Islam. Menjadikan ajaran Islam sebagai pedoman perilaku seharian, baik sebagai anggota masyarakat maupun sebagai ilmuan di tengah-tengah kehidupan masyarakat modern. Mampu mengembangkan dan mengamalkan ilmu serta keahliannya dengan bersumber pada ajaran Islam. Menjadikan ajaran Islam sebagai pedoman perilaku keseharian, baik sebagai anggota masyarakat maupun sebagai ilmuan di tengah-tengah masyarkat modern yang semakin mengglobal, komplek, kompetitif dalam kehidupan masyarakat Selain itu, metodologi pendidikan Islam harus dapat mengembangkan potensi manusia demokratis yang bebas dari ketakutan, bebas berekspresi, bebas untuk menentukan arah kehidupannya.

\section{Prinsip dan Landasan Dalam}

Pengembangan Metodologi Pembelajaran PAI

Metodologi, dalam Kamus Besar Bahasa Indonesia berarti ilmu tentang metode, uraian tentang metode. Dalam Kamus Ilmiah Popular disebutkan bahwa metodologi adalah ilmu metode, ilmu cara-cara dan langkah-langkah yang tepat (untuk menganalisa sesuatu) penjelasan serta penerapan cara. ${ }^{13}$ Metodologi diartikan juga sebagai prinsip-prinsip yang mendasari kegiatan mengarahkan perkembangan seseorang, khususnya proses belajar mengajar. Metodologi merupakan hal yang sangat penting dalam pendidikan Islam. Metode adalah suatu cara mengajar, yang berfungsi sebagai alat untuk mencapai tujuan pembelajaran. Semakin baik metode yang digunakan, maka akan semakin efektif dan efisien pula pencapaian tujuannya. Dalam metode mengajar, faktor guru, siswa, bahan yang akan diajarkan, situasi, sarana prasarana, serta fasilitas-fasilitas lainnya sangat besar pengaruhnya. Dengan banyaknya faktorfaktor yang mempengaruhi di dalam penggunaan suatu metode, maka sebenarnya cukup sulit bagi seorang guru untuk menetapkan metode yang paling baik dan harus dipakai di dalam pembelajaran pendidikan Islam agar pembelajaran tersebut berhasil.

Sedangkan metode mengajar mempunyai definisi sebagai berikut ${ }^{14}$ :

1. Merupakan salah satu komponen dari pada proses pendidikan.

2. Merupakan alat mencapai tujuan, yang didukung oleh alat-alat bantu mengajar.

${ }_{14}$ Moh. Nawafil, Cornerstone of Education : Landasan-Landasan Pendidikan (Yogyakarta: Absolute Media, 2018), 89.
13 Pius A. Partanto and M. Dahlan Al-Barry, Kamus Ilmiah Populer (Surabaya: Arkola, 2004), 84. 
3. Merupakan kebulatan dalam suatu sistem pendidikan.

Jadi pengertian metodologi pendidikan agama Islam ialah segala usaha yang sistematis dan pragmatis untuk mencapai tujuan pendidikan agama, dengan melalui berbagai aktivitas, baik di dalam maupun di luar kelas dalam lingkungan sekolah.

Ada beberapa prinsip dalam pengembangan metodologi pembelajaran $\mathrm{PAI}$ yaitu ${ }^{15}$ :

1. Motivasi. Penerapan metodologi diarahkan untuk dapat memberikan dorongan agar peserta didik aktif belajar dan mengikuti pelajaran.

2. Perhatian. Penerapan metodologi diarahkan untuk dapat membangkitkan perhatian peserta didik agar tertarik terhadap persoalanpersoalan yang disampaikan atau yang sedang dipelajari, melalui penerapan metodologi tersebut.

3. Peragaan. Penerapan metodologi diarahkan untuk dapat memberi kesempatan kepada peserta didik supaya memeragakan atau mendemostrasikan perolehan.

4. Apersepsi. Penerapan metodologi diarahkan untuk dapat dijadikan sebagai sarana penghubung dengan dengan apa yang pernah dikenal oleh peserta didik sebelumnya, berkaitan dengan persolan yang sedang dipelajari.

5. Individualitas. Penerapan metodologi diarahkan untuk dapat dijadikan sebagai saran penghubung dengan bakat dan karakter masing-masing individu peserta didik.

15 Jaenullah, Dkk., "Karakteristik Metodologi Pembelajaran PAI Di Era New Normal," in Prosiding Seminar Nasional Teknologi Pembelajaran, 2021, 590-598.
6. Konsentrasi. Penerapan metodologi diarahkan untuk dapat dijadikan sebagai sarana yang bisa memusatkan daya konsentrasi peserta didik pada persoalan yang sedang dipelajari.

7. Korelasi. Penerapan metodologi diarahkan untuk dapat dijadikan sebagai sarana yang bisa mengajak peserta didik agar dapat menghubungkan mata pelajaran satu dengan lainnya.

8. Sosialisasi. Penerapan metodologi diarahkan untuk dapat dijadikan sebagai sarana yang bisa mengajak peserta didik menyesuaikan dengan keadaan lingkungan sosial.

9. Penilaian. Penerapan metodologi diarahkan untuk dapat dijadikan sebagai sarana yang bisa dipakai oleh pendidik dalam memantau, menilai, dan merekam partisipasi aktif peserta didik dalam memahami, menghayati dan berprilaku dalam belajar.

Di samping itu juga ada beberapa aspek esensial dalam mengembangkan metodologi pembelajaran PAI, di antaranya ialah sebagai berikut $^{16}$ :

1. Niat dan orientasi dalam pendidikan Islam, yakni untuk mendekatkan hubungan antara manusia dengan Allah dan sesama makluk. Pendekatan kepada Allah dilakukan dengan banyak mengingat-Nya yang disertai dengan tauhid, mengesakan Allah. Tauhid ini menjadi ruh bagi aktivitas setiap muslim. Prinsip ketauhidan inilah yang membedakan metode dalam pendidikan Islam dengan metode yang lain.

\footnotetext{
16 A. Fatah Yasin, Dimensi-Dimensi Pendidikan Islam (Malang: UIN-Malang Press, 2008), 131.
} 
2. Keterpaduan (integrative, taubid), dalam arti bahwa dalam pendidikan Islam ada kesatuan antara ilmu-ilmu amal, iman-Islam-ihsan, drikir-fiker (hati dan fikir), zhabir-batin (jiwaraga), dunia-akhirat, serta yang dulusekarang-akan datang. Semuanya harus seimbang, selaras dan menyatu. Kesatuan dan kesalingterkaitan ini marupakan artikulasi dari ketauhidan yang menjadi karakteristik pendidikan Islam.

3. Bertumpu pada kebenaran; dalam arti bahwa materi yang disampaikan itu harus benar, disampaiakan dengan cara yang benar, dan dengan dasar niat yang benar. Mencari kebenaran dan jalan lurus ini harus terus dilakukan selama manusia masih menghembuskan nafas.

4. Kejujuran dan amanah (sidq-amanah). Berbagai metode yang dipakai dalam pendidikan Islam harus memegang teguh prinsip kejujuran (akademik). Kebohongan dan dusta (kid₹b) dalam bentuk apa pun tidak bisa dibenarkan. Misalnya, seorang pendidik (peneliti) harus tetap menyampaikan kebenaran tersebut: katakan kebenaran meski terasa pahit (qul al-haqqa walau kana murran).

5. Keteladanan. Dalam pendidikan Islam ada kesatuan antara iman-ilmu-amal. Pendidik dituntut menjadi contoh teladan bagi peserarta didiknya.

6. Berdasar pada nilai. Metode pendidikan Islam tetap berdasarkan pada nilai etika-moral (alakblak al-karimah). Pendidik yang mengajar praktikum kimia atau geologi misalnya, dia tetap harus menjaga hubungan antara laki-laki dan perempuan, tidak berdua-duan (di ruang tertutup) yang bisa mengakibatkan munculnya fitnah. Hal ini karena metode pendidikan Islam sarat nilai, tidak bebas nilai.

7. Sesuai dengan usia dan kemampuan akal anak (biqadri uquibim). Pendidikan hendaknya diberikan kepada peserta didik setelah mereka berusia minimal tujuh tahun, sehingga mereka mampu merangsang pikiran serta memperteguh keimanan dan daya kreatifnya.

8. Sesuai dengan kebutuhan peserta didik (child center), bukan sekadar untuk memnuhi keinginan pendidik, apalagi untuk proyek semata.

9. Mengambil pelajaran pada setiap kasus atau kejadian (ibrah) yang menyenangkan ataupun yang menyedihkan. Mengambil pelajaran ini dimulai dengan berpikir positif dan menerima perjalan hidup dengan tidak berlebihan dalam menyikapinya.

10. Proporsional dalam memberikan janji (wa'd, tarbib) yang menggembirakan dan ancaman (wa'id, tarbib) utuk mendidik kedisplinan. Proposional karena harus disesuaikan dengan situasi dan kondisi peserta didik.

Adapun landasan-landasan dalam pengembangan metodologi pembelajaran PAI yang merupakan formulasi yang diturunkan dari aspek landasan pelaksanaan pendidikan Islam. karena satu dengan lainnya memilki kaitan yang erat. Adapun landasan dalam pengembangan metodologi pembelajaran PAI yaitu ${ }^{17}$ : 
1. Landasan agama, yakni penerapan metode harus mengacu pada sumber asasi ajaran Islam al-Qur'an dan Hadis.

2. Landasan biologi, yakni penggunaan metode harus memperhatkan kondisi kebutuhan jasmani dan tingkat perkembangan peserta didik.

3. Landasan psikologis, yakni penerapan metode harus disesuaikan dengan kondisi minat dan bakat atau motivasi peserta didik.

4. Landasan sosial, yakni penerapan metode harus disesuaikan dengan tuntutan kebutuhan sosial peserta didik yang selalu berubah dan berkembang setiap saat.

Dalam versi yang tidak jauh berbeda, Fatah Yasin memaparkan beberapa landasan atau asas dalam pengembangan metodologi pembelajaran PAI yaitu ${ }^{18}$ :

1. Asas teologis. Asumsinya bahwa semua peserta didik sejak lahir sudah membawa potensi keyakinan dan kepercayaan kepada tuhan, dan keyakinan tersebut dijadikan sebagai landasan dalam mendorong dan menjalankan tugas serta kewajibannya sebagai hamba Tuhan, termasuk tugas dalam belajar.

2. Asas konstruktivistik. Asumsinya bahwa semua peserta didik memilki kemampuan untuk membangun gagasan/ide/konsep dan mampu melakukan sendiri dalam berbagai hal dalam belajar.

3. Asas kompetitif. Asumsinya bahwa peserta didik memilki kemampuan dan karakteristik yang beragam. Tingkat kecerdasan peserta didik ada yang rendah, sedang dan ada pula yang tinggi, baik kecerdasan intelektual, emosional, maupun spritualnya.

4. Asas partisipatorik. Asumsinya bahwa manusia (peserta didik) adalah mahluk sosial (bomo homoni socius) dan selalu ingin hidup untuk mengaktualisasikan diri bersama dengan orang lain.

5. Asas pencapaian kompetensi. Asumsinya bahwa semua peserta didik apabila belajar tentang sesuatu pasti dirinya ingin menguasai sesuatu yang dipelajarinya tersebut.

6. Asas efektif, efesien, dan senang. Asumsinya bahwa peserta didik dalam proses belajar menginginkan kondisi yang rilex, santai tetapi serius, tepat waktu dan tidak membosankan.

\section{SIMPULAN}

Pendidikan agama Islam mempunyai karakteristik tersendiri yakni sebagai bantuan kepada peserta didik untuk mencapai tingkat keimanan dan berilmu yag disertai dengan pengamalan terhadap perilaku-perilaku terpuji. Hadirnya berbagai masalah dalam bidang pendidikan, seperti masih belum tertanamnya akhlakul karimah secara intensif dan nilai-nilai rohaniyah serta perkembangan zaman yang semakin pesat dengan hiruk-pikuk bumbu digitalisasinya, maka dari itu metode dan mentalitas pendidik perlu mendapat perhatian serius. Metodologi pembelajaran memang bukan merupakan satu-satunya faktor penentu keberhasilan belajar, tetapi proses belajar mengajar pendidikan agama Islam yang baik tidak akan berhasil tanpa metodologi yang tepat dan benar. Melaluli pembelajaran yang menerapkan paradigma holistik, rasional, partisipatori,

18 A. Fatah Yasin, Dimensi-Dimensi Pendidikan Islam (Malang: UIN-Malang Press, 2008), 138. 
pendekatan empiric deduktif, diharapkan dapat mencetak peserta didik yang berkualitas, kreatif, inovatif yang mampu menerjemahkan dan menghadirkan agama dalam perilaku sosial dan individual di tengah-tengah kehidupan masyarakat modern. Landasan-landasan pengembangan metodologi pendidikan agama Islam beberapa di antanya ialah landasan agama, biologi, psikologis, dan sosial.

\section{DAFTAR RUJUKAN}

A. Fatah Yasin. Dimensi-Dimensi Pendidikan Islam. Malang: UIN-Malang Press, 2008.

Agustina, Noni, and Ratnawati Susanto. "Persepsi Guru Terhadap Pengembangan Profesionalisme Melalui Pelatihan Media Pembelajaran Berbasis Edmodo." In Prosiding Seminar Nasional Pendidikan Teknik Informatika, 44-48, 2017. http:/ / pti.undiksha.ac.id/senapati.

Anwar, Qomari. Pendidikan Sebagai Karakter Budaya Bangsa. Jakarta: UHAMKA Press, 2003.

H.A.R. Tilaar. Pedagogik Teoritis Untuk Indonesia. Jakarta: Kompas, 2015.

Hujair AH Sanaky. Media Pembelajaran. Yogyakarta: Safiria Insania Press, 2009.

Jaenullah, Nur Laili, Muhammad Zaini, Habib Shulton, and Dedi Setiawan. "Karakteristik Metodologi Pembelajaran PAI Di Era New Normal." In Prosiding Seminar Nasional Teknologi Pembelajaran, 590-98, 2021.

Kurniawati, Fitri Erning. "Pengembangan Bahan Ajar Aqidah Ahklak Di Madrasah Ibtidaiyah." Jurnal Penelitian 9, no. 2 (2015): 367. doi:10.21043/jupe.v9i2.1326.

Moh. Nawafil, and Junaidi Junaidi. "Revitalisasi Paradigma Baru Dunia Pembelajaran Yang Membebaskan." Jurnal Pendidikan Islam Indonesia 4, no. 2 (April 15, 2020): 215-25. doi:10.35316/jpii.v4i2.193.

Muid, Abdul. "Stategi Penerapan Metodologi Pembelajaran PAI Dalam Meningkatkan Budaya Religiusitas Siswa-Santri Di TPQ Roudlotul Janah Gantang Baru-BobohMenganti-Gresik Jawa Timur." RISDA : Jurnal Pemikiran Dan Pendidikan Islam 4, no. 2 (2019): 12.

Muqit, Abd, Moh Nawafil, and Mohammad Tohir. "Vitality of Educators" Work in Counteracting Students Immoral
Behavior : The Study of Nafs, Qalb and Aql Approaches and Their Theoretical Implementation" 5, no. 10 (2021): 24-31.

Nawafil, Moh. Cornerstone of Education: LandasanLandasan Pendidikan. Yogyakarta: Absolute Media, 2018.

Partanto, Pius A., and M. Dahlan Al-Barry. Kamus Ilmiah Populer. Surabaya: Arkola, 2004.

R, Fadli Muh Suyuti. Dasar-Dasar Pendidikan Islam. Jakarta: Malupu, 2008.

Rohman, Fathur. "Evaluasi Kurikulum Metodologi Pembelajaran PAI Pada Prodi PAI UNISNU Jepara." Tarbawi: Jurnal Pendidikan Islam 12, no. 2 (2015). https://ejournal.unisnu.ac.id/JPIT/article/ view/ 510 .

Rusman. Pembelajaran Berbasis Teknologi Informasi Dan Komunikasi. Jakarta: Raja Grafindo Persada, 2012.

Sri Suyanta. "Transformasi Intelektual Islam Ke Barat." Jurnal Ilmiah Islam Futura 10, no. 02 (February 2011). 